\title{
ZULU STRATEGIC AND TACTICAL OPTIONS IN THE FACE OF THE BRITISH INVASION OF JANUARY 1879
}

\author{
PROF JOHN LABAND \\ Department of Historical Studies, University of Natal, Pietermaritzburg
}

Until recent years, historians of the Anglo-Zulu War of 1879 made little attempt to unravel the strategic and tactical options of the Zulu preparing to face the British invasion of their kingdom. The inadequacy of such an approach was epitomised in the dismissive comments of Donald Morris, whose book, The Washing of the Spears, first published in 1966 and reprinted regularly thereafter, has remained the most popular and influential book on the war. When mentioning Zulu strategic planning, for example, he had nothing to say except that the Zulu king, Cetshwayo kaMpande, had 'no clear plan in mind'.'

It was twenty years ago that I first began to research this aspect of the conflict. I have continued to refine my original conclusions, ${ }^{2}$ which other historians of the war have begun to incorporate into their work. ${ }^{3}$ What my investigations have made quite evident is that the Zulu were indeed aware of the strategic options facing them in 1879, and were conscious of how these were determined by their habitual method of waging war. Consequently, when in January 1879 King Cetshwayo sent out his armies to confront the invader, he did so (pace Donald Morris) with a very clear idea of what he hoped they would achieve militarily, and what effect this was calculated to have on an acceptable termination to the conflict.

\footnotetext{
D. Morris, The Washing of the Spears: A History of the Rise of the Zulu Nation under Shaka and its Fall in the Zulu War of 1879 (London, 1966), p. 360.

See J.P.C. Laband and P.S. Thompson, A Field Guide to the War in Zululand 1879 (Pietermaritzburg, 1979), p.12, modified in J.P.C. Laband and P.S. Thompson, Field Guide to the War in Zululand and the Defence of Natal 1879 (Pietermaritzburg, second revised edition. 1987), p. 18. Exhaustive consideration was given in John Laband, Kingdom in Crisis: The Zulu Response to the British Invasion of 1879 (Manchester, 1992), pp. 53-67.

See, for example, I. Knight, The Anatomy of the Zulu Army from Shaka to Cetshwayo 181181879 (London, 1995), pp. 172-3.
} 
The Anglo-Zulu War was a typical war of resistance to the imposition of colonial rule. Thirty years ago and more, historians of Africa attempted to distinguish specific patterns of reaction to colonial conquest. One school of thought recognized several distinct stages of response, the first being that of 'primary resistance'. This was defined as a movement of resistance to the initial European occupation led by traditional leaders supported by their formal instruments of power, such as their armies. ${ }^{4}$ Though so long current, this concept is still appropriate when considering the options open to the Zulu leadership engulfed by the invasion crisis of 1879 .

Ross Hassig, in his illuminating study on Aztec warfare, reminds us that its practice (so strange and even repugnant to a contemporary mind) was nevertheless a logical exercise in political power to secure the integrity of the state, explicable in strategic terms and possessing a rationality as accessible as our own is to us. ${ }^{5}$ So it was with the Zulu response to the threat of the British invasion. After all, as Geoffrey Best has argued, human society, once politically organised, becomes a state, and states distinguish themselves from other states by their ability to fight in order to further their own interests or to protect themselves from one another. ${ }^{6}$ A war, then, is a function of state politics, and marks the conviction by a state that it can impose its will on another most effectively through fighting. Yet war is of a reciprocal nature, for the aggressors's assumptions about possession of a relative advantage are matched by others held by the prospective victim. If the latter should contemplate resistance, it is because it perceives that the hostile power threatens its own ability to control the environment securely. An environment on which its independent existence and the cultural values of its society depend. ${ }^{7}$

For a discussion of various categories of resistance, see J.P.C. Laband. 'The nature of the Indian Mutiny: a changing concept', Theoria, XLVI (May 1976), pp. 32-4.

R. Hassig, 'Aztec warfare', History Today, 40 (February 1990), p. 24.

G. Best, 'Introduction' to V.G. Kiernan, European Empires from Conquest to Collapse, 1815 1960 (Bungay, 1982), p. 8.

See M. Howard, The Causes of Wars (London, 1983). pp. 13, 18: M. Howard. 'Military power and the international order' in J. Garnett (ed.), Theories of Peace and Security (London, 1970). p. 41; G. Blainey, The Causes of War (Melbourne, 1977), pp. 104, 149-50; T.C. Schelling, Arms and Influence (New Haven, 1966), pp. 1-3; T.C.W. Blanning. The Origins of the French Revolutionary Wars (Harlow, 1986), pp. 26-7; D. Kagan, On the Origins of War and the 
Nevertheless, if resistance to an external threat is to be an option, a state must consider its military capability. The crucial decision at the moment of crisis is whether or not to take up arms. The victim of aggression does possess options.If it finally calculates that its military power is indeed inferior to that of its enemy, then it must either submit to the demands being imposed, or embark with open eyes on a hopeless war where nothing is to be saved except honour. On the other hand, it might consider that its enemy has overestimated its relative strength, and that more is to be gained by fighting than through capitulation. ${ }^{8}$ If fighting is the choice adopted, it is essential to accept, as Blainey reminds us, that it is often realistic to hold a humbler definition of what constitutes success in a war other than all-out victory, and that it in certain circumstances it makes sense to resist in the belief that defeat and submission can be avoided, rather than in the deluded hope that the war can actually be won. ${ }^{9}$ This perspective is particularly apposite when considering how the Zulu viewed the purpose of their resistance in 1879 to a technologically far superior opponent, and when assessing whether such an approach could conceivably have succeeded.

In response to the crisis engineered in 1878 by Sir Bartle Frere ( the British High Commissioner for South Africa) in his determination to eliminate the military capability of the independent Zulu kingdom, which he perceived as the main stumbling-block in the way of his confederation scheme for southern Africa, the Zulu king had to make the classic choice between capitulation or war. ${ }^{10}$ However, the draconian terms of the British ultimatum delivered on 11 December 1878 made compliance

Revolutionary Wars (Harlow, 1986), pp. 26-7; D. Kagan, On the Origins of War and the Preservation of Peace (London, 1997), pp. 6-7.

Blanning, French Revolutionary Wars, pp. 21, 26-8; Blainey, Causes of War, pp. 158-9.
Ibid., p. 53 .

This paper does not seek to analyse the controversial causes of the Anglo-Zulu War, which have long been a matter for intense scholarly debate. However, the range of the controversy can be gauged by consulting the following: J. Guy. The Destruction of the Zulu Kingdom: The Civil War in Zululand, 1879-1884 (London, 1979), pp. 41-51; C. de B. Webb, The origins of the Anglo-Zulu War: problems of interpretation' in A. Duminy and C. Ballard (eds). The AngloZulu War: New Perspectives (Pietermaritzburg, 1981), pp. I-12; N. Etherington. 'Anglo-Zulu relations, 1856-78' in ibid., pp. 13-52; Laband, Kingdom in Crisis), pp. 4-17; R.L. Cope, 'The origins of the Anglo-Zulu War of $1879^{\prime}$ ( Ph.D. thesis, University of the Witwatersrand, 1995: to be published in late 1998 by the University of Natal Press), passim. 
impossible if the independence of the Zulu kingdom were to be maintained, and the social and economic system upon which the king's political power was based were not to be fatally subverted. Consequently, King Cetshwayo allowed the ultimatum to lapse unanswered on 11 January 1879 , and employed the intervening thirty days of grace to perfect his strategic response to the impending invasion.

Lieutenant General Lord Chelmsford, who planned the British invasion, had put together an invading force of 17929 men (5 476 of whom were British regulars) which he had divided into three main columns. These columns were to converge on oNdini, Cetshwayo's capital, and it was intended that during their advance they would entice the Zulu into risking one or more pitched battles. Once committed, the Zulu would discover to their cost (or so the British reckoned) that their superior numbers were no match for modern, well-trained troops and devastating fire-power of the British. "I

To face this formidable threat, the Zulu possessed a military organisation that was on a militia basis and geared to short campaigns. ${ }^{12}$ This military system was built upon the institution of age-set units, or 'regiments', called amabutho (singular - ibutho). Boys between the ages of fourteen and eighteen would gather at the various military homesteads (amakhanda, singular - ikhanda), which were regional centres for royal influence and mobilisation points for the amabutho. There youths would serve for two to three years as cadets. Once enough boys of an age-group were congregated at the various amakhanda around the kingdom, the king would form them into a new ibutho with orders to build a new ikhanda. A new ibutho would serve continuously for seven to eight months immediately after formation, and thereafter for only a few months a year, leaving the men free for the rest of the year to attend to their own homesteads. Older men, once they had been given permission at about the age of thirty-five to marry, would perform their service at an ikhanda accompanied by their wives. While serving at an ikhanda, amabutho kept

For a discussion of Chelmsford's invasion plans, see John Laband (ed.), Lord Chelmsford's Zululand Campaign 1878-1879 (Stroud, 1994), pp. xxx-xxxvi.

For a detailed description of the ibutho system, see, Laband, Kingdom in Crisis, pp. 18-22; Knight, Zulu Army, pp. 46-90. 
it in repair, tended the king's cattle and fields, participated in great hunts, collected tribute, acted as an internal police force, played their part in the great national ceremonies, and mustered - when occasionally required for war.

Any strategy King Cetshwayo and his councillors might devise in 1879 depended on the number of amabutho actually available for campaign. Their strength is difficult to estimate with any certainty. In the booklet on the Zulu army, which he compiled in 1878 on Chelmsford's orders, the Natal official, F.B. Fynney, calculated the Zulu army at 41 900 men. $^{13}$ Other colonials at the time estimated the army to be as large as between 50000 and $60000 .^{14}$ In fact, the Zulu army probably did have a nominal strength of about 40000 , but some of the senior amabutho would have been too old for active service, while not every member of an ibutho would have mustered when summonsed. Probably the estimate reached in January 1879 by J.E. Fannin (the Special Border Agent in Umvoti County) that 29000 Zulu warriors had mobilized is substantially correct. $^{15}$

The king learned from his deployment of spies in Natal, the Transvaal and Delagoa Bay, the precise strength and intentions of the British columns poised to invade his kingdom. ${ }^{16}$ Knowledge of the magnitude of the threat and the limits of his own resources caused Cetshwayo to cast around for potential allies. This was a perfectly natural response, for any belligerent, on contemplating the possibility of going to war, must assess how intervention by outside parties might affect the course of the impending conflict. Such predictions, especially if optimistic, will play an important part in military planning. ${ }^{17}$ But in Cetshwayo's case, there was little like likelihood of gaining help from

\footnotetext{
13 F.B. Fynney, The Zulu Army and Zulu Headmen. Published by Direction of the Lieut.-General Commanding (Pietermaritzburg, 1878).

14 Natal Colonist, 24 October 1878: Lower Tugela correspondent, 21 October 1878.

15 Papers of the Colonial Secretary's Office, Natal, held in the Natal Archive's Depot, CSO 1925, no. 488/1879: Fannin to Colonial Secretary, 21 January 1879. Mpande on the History and Customs of his People (Pietermaritzburg and Durban, 1978), p. 30; Chelmsford Papers held in the National Army Museum, Chelsea, CP 16/13: statement of Zulu prisoner Mungundela, taken by Bengough's men on 13 May 1879. Blainey, Causes of War, pp. 44, 57-8.
} 
neighbouring African chiefdoms. Indeed, the hard truth was that during the process of the closing of the southern African frontier, which accelerated during the $1870 \mathrm{~s}$, African chiefs rarely (if ever) succeeded in forming large-scale alliances. Though they maintained diplomatic relations (which, in Cetshwayo's case, were consistently misrepresented as proof that he was orchestrating a black conspiracy against white rule in southern Africa), ${ }^{18}$ sectional advantage was regularly placed before wider, common interests. ${ }^{19}$

Thus, there was never any possibility, despite some pre-war negotiation, of any help from Swaziland. To the contrary, that mountainous kingdom to the north of Zululand had been a victim of Zulu expansionism ever since the days of King Shaka, and looked forward to an end to Zulu military might. ${ }^{20}$ Nor was there any chance of cooperation with the Mabhudu-Tsonga, the dominant chiefdom across the trade-routes to Delagoa Bay. Although they paid tribute to the Zulu, relations had been poor since the $1860 \mathrm{~s}$ as both Mabhudu-Tsonga and Zulu were attempting to control the lucrative trade and the smaller chiefdoms of the region. The Mabhudu-Tsonga, like the Swazi, would only have welcomed the breaking of Zulu power. ${ }^{21}$ Further afield, Cetshwayo had even less chance of raising black chiefdoms under British suzerainty against their overlord. Despite the activities of his emissaries in late 1878, he had absolutely no success with the Sotho, under the authority of the Cape Colony since 1871 , nor with the Mpondo in the eastern Cape. ${ }^{22}$ It should perhaps have been different with Sekhukhune, the Pedi chief. He had determinedly held the Boers of the South African Republic at bay for

\footnotetext{
18 See, among the host of statements to this effect, the comments of Frere's Military Secretary: Capt. H. Hallam Parr, A Sketch of the Kafir and Zulu Wars (London. 1880), pp. 96-102, 118.

19 C. Saunders, 'Political processes in southern African frontier zones' in H. Lamar and L. Thompson (eds), The Frontier in History: North America and Southern Africa Compared (New Haven and London, 1981), p. 162.

20 See P. Bonner, Kings, Commoners and Concessionaires: The Evolution and Dissolution of the Nineteenth-Century Swazi State (Johannes burg, 1983), pp. 147-52.

21 See P. Harries, 'Labour migration from Mozambique to South Africa with special reference to the Delagoa Bay hinterland, c. 1862 to $1897^{\prime}$ (unpublished Ph.D. thesis, University of London. 1983), pp. 147, 167, 179-81; Harries, 'History, ethnicity and the Ingwavuma land deal: the Zulu northern frontier in the nineteenth century', Journal of Natal and Zulu History, VI (1983), pp. 12-13, 17.

22 See, for example, British Parliamentary Papers (henceforth BPP) (C.2260), sub-enc. 14 in enc 2 in no. 6: Major C. Bell to Governor's Agent, Basutoland, 4 October 1878; and papers of the Secretary for Native Affairs, Natal, held in the Natal Archives Depot.
} 
years, and though the British had annexed the territory in April 1877 as the Transvaal Colony, their campaign against the Pedi had also ended in failure by October 1878. There is evidence that Sekhukhune and Cetshwayo were indeed considering a common anti-British front but, in the event, no active alliance was formed. It seems that the Pedi found it more expedient not to allow their unresolved conflict to become embroiled with the Zulus' explosive dispute with the British. ${ }^{23}$ Despite serious efforts, therefore, Cetshwayo failed to forge an alliance with any other African rulers against British aggression. Consequently, by January 1879 Cetshwayo knew that he would have to face the British alone.

Precisely because he understood that he did not have enough resources to wage an aggressive campaign against his colonial neighbours that could dramatically turn the tables on them, Cetshwayo resolved that he would adopt an essentially defensive military strategy. This approach fitted in well with his political strategy which aimed at presenting the king to the world as the passive victim of an unwarranted attack, legitimately fighting in self-defence strictly within the borders of his own kingdom. ${ }^{24}$ Cetshwayo therefore insisted that his armies, even if successful, were not to follow up their victory with an invasion of the neighbouring British colonies. He knew from his white advisers, in particular John Dunn (the hunter-trader who supplied the king with guns, and who in return had been rewarded with a large chiefdom), that the British had limitless resources. Consequently, the longer the war lasted and the more extensive its scope, the less chance the Zulu would have of winning it. A violation of British territory would only serve as a gratuitous provocation, requiring a comprehensive British victory to underline their paramountcy in the sub-continent. The Zulu campaign had accordingly to be both limited and swift. Cetshwayo's hope was that if the Zulu armies, after successes in the field, were able to threaten the borders of the Witwatersrand, 1878), pp. 173-6; P. Delius, The Land Belongs to Us: The Pedi Polity, the Boers and the British in the Nineteenth Century Transvaal (Johannesburg, 1983), pp. 236, 238. Webb and Wright, Zulu King Speaks, pp. 29-31, 55-6; C. Vijn, (tr. from the Dutch and edited with preface and notes by the Rt. Rev. J.W. Colenso, D.D., Bishop of Natal) Cetshwayo's Dutchman; Being the Private Journal of a White Trader in Zululand during the British Imvasion (London, 1880), pp. 31, 96-7: H. Rider Haggard, Cetywayo and his White Neighbours; or, Remarks on Recent Events in Zululand. Natal and the Transvaal (London, 1888), p. 34. 
of Natal or the Transvaal, then he would be able to negotiate from a position of strength, and the British would be pressured into concluding an acceptable settlement before reinforcements could arrive from overseas. $^{25}$

In practical terms, the implementation of this strategy of limited objectives required the most effective positioning of the Zulu forces available. Not only were three British columns set to invade the kingdom from widely separated points to the south, west and north-west, but there was the real possibility that the British would attempt a sea-borne invasion from St Lucia Bay and Delagoa Bay and, with Mabhudu-Tsonga aid, advance from the north-east. Furthermore, there was every likelihood that the hostile Swazi would attempt an invasion from the north. ${ }^{26}$ Faced, therefore, with possible attack from every quarter, Cetshwayo decided to give priority to concentrating his efforts against the two British columns operating out of Natal, so that any success in the field would enable him to threaten that colony and force a peace. His spies told him that the British Centre Column operating out of Rorke's Drift was the strongest column, and that Chelmsford himself was accompanying it. This information persuaded Cetshwayo that this was the main British force, and that the maximum effect would be gained by defeating it. $\mathrm{He}$ consequently directed his main army against the Centre Column, while a much smaller force moved against the Right Column preparing to advance into Zululand across the Lower Thukela. He also sent some reinforcements to support the locally raised forces facing the Left Column and its Boer allies; while some local irregulars collected in the Nkandla forest to repel any possible British advance (there was none) across the middle Thukela. ${ }^{27}$

The commitment of available Zulu forces to the southern and western borders of the kingdom might seem to have left it vulnerable to attack from the north and north-east. Yet, as events turned out,

\footnotetext{
2s Webb and Wright, Zulu King Speaks, pp. 30-1.

26 lbid., p. 55.

$27 \quad$ Ibid., p. 32 ; BPP (C. 2260), no. 10: statement of Ucadjana, son of Matendeka, taken by H.C. Shepstone, 3 February 1879; BPP (C. 2252), no. 20: Wood to Military Secretary, 18 January 1879; CSO 1925, no. 488/1879: Fannin to Colonial Secretary, 21 January 1879.
} 
Cetshwayo was right in discounting a serious incursion from the sea or across the Phongolo. Certainly, he retained a small reserve of elderly amabutho at oNdini to intercept an unlikely dash by a mounted British force into the interior, but this was only a token force. ${ }^{28}$ For by January 1879 it was clear that the British were not preparing to land a force at Delagoa Bay, even though the Portuguese had been willing to allow them passage. ${ }^{29}$ Nor were they going to attempt an amphibious landing further down the Zululand coast despite a serious attempt in August 1878 to find a suitable landing-place. ${ }^{30}$ Cetshwayo was less confident, however, in leaving his borders with Swaziland exposed, though here again he read the situation correctly. Nothing, it transpired, would induce the Swazi to risk entering a war as allies of the British against their hated and expansionist Zulu neighbour until they were absolutely certain they would be on the winning side. Such assurance would not be forthcoming until the campaign had developed. Despite repeated overtures by Norman MacLeod, the Swazi Border Commissioner to King Mbandzeni, the Swazi consequently prevaricated and contented themselves in January 1879 with standing uncommitted, but on the alert. ${ }^{31}$ Correct, therefore, in his strategic assessment of the forces ranged against him, Cetshwayo could neglect his northern border and coast to concentrate on the British preparing to advance from the south and west.

Some historians have nevertheless been puzzled by a number of aspects of the Zulu leadership's strategic and tactical decisions in 1879 . When Cetshwayo sent off his armies it was with the firm conviction shared by his people - that if they could only force the British to give battle in the open field, they would envelope the enemy in the classic bull's horns manoeuvre and overwhelm him in hand-to-hand fighting with their numerically superior forces. ${ }^{32}$ As early as 1971, Jeff Guy

28 Webb and Wright, Zulu King Speaks, pp. 30, 32.

29 Colonial Office, CO 179: original correspondence, Secretary of State, vol. 131, pp. 464-5: R.D.B. Morier to Lord Salisbury, 15 February 1879. CO 879/14: African Confidential Print 162, enc. in no. 248: Capt. E. Baynton to Commodore F. Sullivan, 23 August 1878; Fleet-Surgeon H.F. Norbury, The Naval Brigade in South Africa during the Years 1877-78-79 (London, 1880), p. 219. 
questioned in a seminal article why the Zulu insisted on fighting pitched battles and did not consider attempting a protracted, guerrilla-style defensive strategy that might have prolonged the campaign beyond British endurance. $^{33}$

Besides Cetshwayo's keen awareness (discussed above) of Britain's unlimited resources and the need to force a quick decision before they could be brought to bear, the answer, I suggest, lies in the nature of the Zulu ibutho system. As members of a militia, Zulu soldiers were required at key times of the agricultural year to maintain the domestic economy. Besides, if Zulu soldiers, women, children, old people and their livestock had withdrawn to their traditional fastnesses in forests, caves and on flat mountain-tops, how long could they have remained provisioned? Moreover, could a martial people who, ever since the time of King Shaka, had been used to raiding enemy territory far from home, have tolerated the systematic destruction of their homes and crops and the driving off of their livestock? The devastation wrought by the advancing Second Division and Flying Column in May.-July 1879 demonstrated just how effective such wide-spread British raiding could be. Consequently, for material reasons connected to the economic and social consequences on the civil population, quite beyond the psychological preferences of amabutho trained for conventional military engagements, the irregular warfare option was never conceivable. It was therefore unavoidable that Zulu strategy in 1879 , which hinged on a substantial success in the field to be followed by a settlement negotiated from a position of strength, coincided precisely with the British preference for a swift campaign decided by a pitched battle.

Yet even if it is accepted that the Zulu were wedded to the strategic idea of seeking a decisive, set-piece battle, it has still remained centrally problematical for historians why they had failed to develop new tactics better suited to confronting the devastating fire-power of the invading British. After all, as Norman Etherington pointed out in his review of my book, Kingdom in Crisis, neighbouring African societies like the Pedi and

See J. Guy, 'A note on firearms in the Zulu kingdom with special reference to the Anglo-Zulu War, 1879', Journal of African History, XII, 4 (1971), pp. 565-6. 
Sotho had adopted new technologies and tactics over the years, and by the 1870 s were adept with guns and horses in waging irregular warfare. Why, pursued Etherington, should the Zulu by contrast have been so conservatively attached to the outmoded tactics of the 1830 's? ${ }^{34}$

There are, I believe, a number of answers to these conundrums. First, unlike the Xhosa, for example, who over a period of a hundred years between 1779 and 1878 had fought nine Frontier Wars against the powers of colonialism, or the BaSotho, who had waged three wars with the Boers of the Orange Free State between 1858 and 1867, the Zulu had last confronted white forces forty-one years prior to the British invasion of 1879. Since the series of battles and skirmishes with the Emigrant Farmers in 1838, the Zulu had fought many battles, but all until 1879 had been with African forces employing conventional fighting techniques with some firearms in a strictly auxiliary role. This was true whether with regard to the campaigns against the Swazi of 1839, 1847, 1848 and 1852, or to the civil wars of 1840 and $1856 .{ }^{35}$ Consequently, crack amabutho in the prime of their lives in 1879 would never have faced white troops in battle; while those with combat experience in any major campaign at all would have been in their middle forties or older. ${ }^{36}$

Secondly, reinforcing the ingrained preference for the pitched battle culminating in courageous hand-to-hand combat. (Conducted according to an ordered and predictable formula $)^{37}$, were technological reasons why the Zulu failed to make effective use of what firearms they possessed. Since the 1860 s firearms had been entering Zululand in ever-increasing numbers through Delagoa Bay and Durban, so that by 1879 there were probably about 20000 in the kingdom. The prestige and power conferred by these weapons were not lost on the king who tried unsuccessfully to

$34 \quad$ N. Etherington, 'Review of Kingdom in Crisis', Journal of Imperial and Commonwealth History, 21, 2 (May 1993), pp. 466-7.

35 For a description of the Swazi campaigns and the civil wars of the 1840 s and 1850 s, see J. Laband, Rope of Sand: The Rise and Fall of the Zulu Kingdom in the Nineteenth Century (Johannesburg, 1995), pp. 110, 116-18, 131-2, 142-6.

36 For the probable ages of amabutho involved in the Anglo-Zulu War, see E.J. Krige, The Social System of the Zulus (Pietermaritzburg, 1950), pp. 405-7.

37 See J.B. Wright and C. de B. Webb (eds), The James Stuart Archive of Recorded Oral Evidence Relating to the History of the Zulu and Neighbouring Peoples (Pietermaritzburg and Durban. 
preserve them as a royal monopoly. Several thousand were modern rifles, and there were probably a few hundred men in the kingdom who, from involvement in the gun-trade and hunting, knew how to use them and would prove not ineffective during the 1879 campaign as snipers. But the great majority of firearms were obsolete muzzle-loaders, and the men who carried them were inadequately trained in their use and did not know how to operate the sights correctly. The perceived limitations of these consequently inaccurate and faulty firearms, persuaded most amabutho to employ them solely as secondary weapons in place of throwing-spears, to be discharged at a distance and then to be thrown aside in favour of the stabbing-spear as they charged home. ${ }^{38}$

The third - and more significant point, (I would argue) in explaining the traditionalism of Zulu tactics in 1879 than the matter of limited appropriate battle experience and lack of confidence in their firearms - is the fact that the Zulu believed that if they could only force the British to give battle in the open field, they would overwhelm the enemy with their numerically superior forces deployed for the traditional mass frontal attack. ${ }^{39}$ After all, when the Boers had left the protection of their wagonlaagers in 1838, Dingane's amabutho had routed their commandos on 10 April at eThaleni and again at the White Mfolozi on 26 December. They had also made short work in similar circumstances of the Voortrekkers' Port Natal allies at Ndondakusuka (the battle of the Thukela) on 17 April. ${ }^{40}$ Why should these successes not be repeated against the British in 1879? But battle had to be in the open, as in the three instances mentioned. Zulu tacticians had not failed to learn from the negative lessons of 1838 when at Veglaer on 13-15 August - and even more notably at Blood River on 16 December $^{41}$ - the amabutho had been thrown back with extraordinarily heavy losses from the carefully prepared and stoutly defended Boer wagon-laagers.

1982), vol. III, pp. 301, 325: testimony of Mpatshana ka Sodondo, taken on 24 and 31 May 1912. pp. $62-5$.

CP 8, no. 49: report by Bishop Schreuder on conversation with the induna Ulankana son of Undikile, 10 February 1879.

See Laband, Rope of Sand, pp. 92-4. 103-4.

See ibid., pp. 95-6, 98-102. 
The dangers involved in trying to storm prepared positions such as laagers or forts were consequently all too evident, and King Cetshwayo categorically forbade his departing armies to attack any form of entrenchment where they would be pitilessly exposed to concentrated British fire-power. Instead, he ordered his generals to bypass all prepared enemy positions. By threatening both British lines of supply and the territory to their rear, this strategy was calculated to force the invaders to come out of their defensive works, to fight in the open. Alternatively, Zulu commanders should surround the entrenched British at a safe distance (as was later to happen at Eshowe) and attempt to starve them into submission or a disadvantageous sortie. ${ }^{42}$

As sound as this strategy might have seemed in theory, it was nevertheless flawed at two levels. Its objective, as has been shown, was to bring the British into the open, but there was no guarantee that the Zulu would win a pitched battle in these circumstances, whatever their optimistic expectations. At Isandlwana on 22 January 1879 the extended British firing-line delivered a sufficiently concentrated fire to pin down the Zulu centre until outflanked - even though the intervals between the troops in some companies were as far apart as ten paces and never less than about four. At Nyezane on the same day, although ambushed in vulnerable extended marching order, the British were able to close up efficiently and quell the Zulu attack in what amounted to an extended fire-fight. ${ }^{43}$

Nor, did this strategy properly recognise the practical difficulties involved in actually keeping a Zulu army in the field supplied long enough to force the enemy to offer battle outside their entrenchments. For a Zulu army carried provisions sufficient for only a few days, and thereafter it depended on limited stores held in the district amakhanda or on what it could forage from homesteads in the vicinity. Furthermore, such a strategy required considerable discipline and patience on the part

CP 8, no. 49: report by Bishop Schreuder on conversation with Ulankana, 10 February 1879: Vijn, Cetshwayo's Dutchman, p. 39.

See Infantry. Field Exercises and Evolutions of (London, 1877), pp, 53-4: Laband, Rope of Sand, pp. 225, 244-6 
of the blockading army. But younger amabutho in particular, who were headstrong and highly competitive in their search for military glory, were notorious for their lack of restraint, and it would take exceptional skill and strength of will on a commander's part to bend them to such lacklustre operations. Furthermore, it was usual practice for a Zulu army to disperse immediately after action for the absolutely necessary purification ceremonies following the ritually polluting shedding of blood, to report their deeds to the king, to share out the booty, and to recuperate from fatigue, hunger and wounds. ${ }^{44}$ The inevitability of such a dispersal after combat rendered it effectively impossible to concert strategy over a lengthy campaign; indeed, in 1879 the Zulu armies dispersed after each increasingly disheartening series of battles and had to be mustered again for the next round.

At the beginning of this paper I suggested that the victim of aggression will resist if more is to be gained through fighting than through capitulation, even if the objective is the limited one of avoiding submission rather than actually winning outright. The Zulu king and his advisers went to war in 1879 with that intention. They calculated that their armies, deployed with due regard to the limited forces available and the correctly perceived strategic intentions of their enemies, could win successes in the field that would paved the way for an acceptable negotiated peace. In the event, and for the reasons discussed, both strategic and tactical Zulu expectations proved ill-founded, and their conventional military methods fatally outmoded. That the Zulu forces gained spectacular military successes against the British at the battles of Isandlwana, Ntombe and Hlobane, as well as in several skirmishes such as at eZungeni, was a consequence more of British over-confidence or incompetence than an indication of inherent Zulu strategic and tactical superiority. Sometimes, as I pointed out earlier, the decision to resist amounts to no more than an emotional determination in the face of hopeless odds to salvage honour when all else is likely to be lost. That was not how the Zulu saw the situation in January 1879 with the British

For a discussion on Zulu logistics, military discipline, dispersal and ritual purification. see Laband, Kingdom in Crisis, pp. 65-7, 109-110. 